\title{
The Role of Sport in the Process of Negotiating Identity: Dealing with the Stigma of Disability by People with Acquired Bodily Dysfunctions
}

\author{
Jakub Niedbalski \\ University of Lodz, Poland
}

DOI: http://dx.doi.org/10.18778/1733-8077.16.4.11

\section{Keywords:}

Disability; Body; Stigmatization; Sport; Identity; Symbolic Interactionism

\begin{abstract}
This paper is intended to present the role of sport in the lives of people with physical disabilities and to determine how practicing sports changes the way a person with a physical disability sees themselves. The paper reflects the experiences of people who started practicing sports, which allowed them to adopt an alternative perspective of their bodies and thus pushed them to negotiate their identities. Using the concept of Goffmanian stigma, I point to the sports activities' usefulness in understanding the management of stigma by those dealing with a physical disability.

Taking into account the above theoretical references, in the research, which constitutes a foundation of this paper, I refer to the subjective perspectives of the researched individuals, rendering their points of view, and, based on that, construct and offer theoretical generalizations. Therefore, the research materials employed in this study are constituted by the personal experiences of people with physical disabilities who practice sports. All data have been gathered by conducting unstructured interviews with such people. The research materials were analyzed and interpreted following the procedures of grounded theory methodology.
\end{abstract}

Jakub Niedbalski, a sociologist, is a research and teaching staff member employed in the Department of Sociology of Organization and Management of the Institute of Sociology, University of Lodz. He specializes in the computer-assisted analysis of qualitative data, qualitative research methods, the sociology of disability, and the sociology of sport. He researches the social activation of people with disabili- ties, as well as on the situation of families with people with disabilities, including entities and institutions supporting them. He is the author of several dozens of scientific publications devoted to the issues of disability, social assistance, as well as the qualitative research methodology.

email address: jakub.niedbalski@uni.lodz.pl 


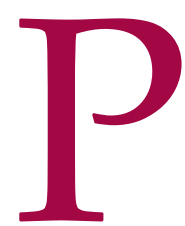

eople with disabilities constitute a social category that is often referred to in the context of exclusion and marginalization (Kirenko 2006:101). This marginality refers to an individual with a disability or a social group (the disabled) in terms of various forms of their functioning: the sphere of production, consumption, as well as social, political, or broadly understood cultural spheres, defining the possibility of performing social roles corresponding to the standards of dominant groups. The marginal situation of people with disabilities is accompanied by numerous stereotypes. In general, the stereotype of a person with a disability is dominated by two characteristics-one is their weakness (weak, fearful, insecure), while the other justifies the lack of acceptance and social isolation of this group of people (suspicious, secretive, lonely). The stereotype of a person with a disability defines two main parameters-mentally weak and socially isolated (Ostrowska 1994:43-45). Therefore, people with disabilities bear various labels that are characterized by negative moral judgments and express fear and pity, and sometimes contempt or disgust (Niedbalski 2013:38). This seems to confirm the dominant position and superiority of the stigmatizing over the stigmatized and means that normalsin this case, healthy people-are inclined to value themselves and other people from their group differently in comparison to the stigmatized, the disabled. They tend to perceive "their persons" (the fully capable) as more valuable (Czykwin 2008:19). The negative stigma accompanying disability leads, on the other hand, to the devaluation of the person as a bearer of stigmatizing characteristics (Crocker and Major 1989; Major and O'Brien 2005; Heatherton et al. 2007). Thus, the stigma is equivalent to the situation of an individual deprived of full social acceptance (Goffman 1963:27). According to Goffman (1963), the stigmatized have an attribute that disqualifies them in the eyes of others and excludes them from full acceptance by their social environment. People who receive incomparably more unpleasant feedback about themselves because of the stigma can form a negative identity. Often, they also have underestimated self-esteem and a sense of dignity (Czykwin 2008:19). A dehumanization process associated with exclusion can, in extreme cases, lead to an increase in feelings of guilt, as well as weakening or losing identification with others and their reification (Czykwin 2008:20).

Taking into account the above issues, the paper aims to bring closer the situation of people with disabilities, revealing the problem of exclusion and stigmatization, but also to show how sport and physical activity can counteract those negative phenomena which members of our society with disabilities are exposed to. Therefore, the discussion will be focused on the issue of experiencing one's own body by people with physical disabilities in the course of construing identity, accompanied by the process of maintaining a positive image of self-threatened by externalization of the stigma related to the social perception of bodily deficits. The objective results of a disability are accompanied by subjective transformations in the self of an individual and in the arrangement of categories and assessments applied to themselves and other people that are related to the reconstruction of the image of their previous lives and themselves (Carey 2013:142). One's bodily dysfunction can affect the entire self-definition of an individual, concerning various social roles and contexts, such as the family, work, or simply relationships with other people (Charmaz 1995). It is a process in a mental sense, connected with the development of a certain cognitive perspective. The course of this process triggers numerous factors, and its effect is a reconstructed identity of the individual (Strauss 1959). This is relat- 
ed to transformation in self-narration and self-perception by a person with a disability (Charmaz and Rosenfeld 2006). This means that an individual with a disability changes their view on reality and themselves in a more or less conscious way.

Therefore, the text will include an analysis of the determinants of a person's body perception in the various categories of inadequacy, as well as their social consequences. For this to happen, it is vital to see the body as an element of identity, a source of stigma, an object of property, and a place of social control (Charmaz 2019:19). The analysis is mainly focused on grasping the processual dimension of the transformations which take place in the self-perception by people with disabilities who have found the source of inner strength and ability to oppose the stigmatizing reality in sports, thus winning the process of reconstructing their identity.

\section{The Literature Review and Theoretical Considerations}

In this paper, the basis of the analyses carried out is an interpretative perspective-describing the world in the categories of reality construed in the course of symbolic interaction. According to the assumptions of the above paradigm, it has been assumed that individual actions are taken in specific situational and interactive contexts, thus resulting from the interpretation of a given event, situation, or phenomenon by a specific social actor. The definition of a situation is co-created and maintained in the course of interaction. Symbolic interactionists are inclined to perceive people as active social actors who continuously reconstruct a picture of surrounding reality and their place in the life of a given community. Robert Prus and Scott Grills (2003:19) believe that symbolic interaction "may be perceived as an exam- ination of the ways in which people provide meaning to their life situation and interact with others on an everyday basis." Herbert Blumer (1969:48) argues that "the process of interacting with oneself places a human being before the world, not within it, thus causing the need to deal with the world through the process of defining and not just responding to it." However, to become an object for ourselves, we first need to become an object for others (Marciniak 2015:44). Using a metaphorical comparison, we can say that we need a mirror in the form of other people in which we can put ourselves in their roles (Cooley 1922; Scheff 1990). Therefore, the reality of subjects appears as a configuration of certain meanings, the sense of which can be discovered as long as the experiences of people who produce them can be captured.

The leading theory explaining the phenomena analyzed in this paper is the concept of stigma (Goffman 1963), which allows the understanding of the mechanism of the formation of unfavorable social attitudes and barriers of awareness separating a person with a disability from society. According to Elżbieta Zakrzewska-Manterys (2010:123), using the conceptual framework proposed by Goffman (1963), disability can be treated as "an archetype of stigma, as something that is stigmatized almost always and by many, and as a kind of stigma that is not always realized by those stigmatized."

From the perspective of capturing and understanding the phenomenon of stigmatization of people with disabilities, it is important to reach for the etymology of the word "disability" itself, which in Poland appeared in the official nomenclature in the 1970s (Zakrzewska-Manterys 2010:46). Previously, words such as "cripple" or "invalid" were applied to label people with physical disorders. However, 
regardless of the way disability is defined, it has always been described as something unnatural, deviating from accepted standards, and the people with disabilities were usually attributed to various negative features. This is how a relatively clear social image of people with observable and embodied disorders was developed. It resulted from the fact that great importance was attached to the signs of "normality" seen in people's behaviors and appearance (Niedbalski 2015a:222). The canons of beauty and ugliness, normality and deviation, have changed over the last few centuries, but there have always been clear boundaries defining what is and what is not accepted as being compliant with common standards legitimized by members of a given society in a given time and space (Kowal 2012:164). Human corporeality is also subject to such criteria, and as an area of social control, it can be evaluated as a product of this control. It happens because a body significantly determines who we are, how we perceive ourselves, and how others perceive us. While determining the human identity in an increasingly more significant way, it also needs to determine our place in the social hierarchy (Mason 1990:17).

Therefore, identity covers personal and mental elements, which are unique, as well as inherited ones, such as appearance, sex, race, ethnicity, age, experience, and social position. It is something that shapes the identity and social biography of individuals (Konecki 2015:17). Identity grows based on the awareness of one's own physical and mental potency; it is a creation of an evolutionary process, related to the human ability to develop, advance, and adapt to the surrounding world, and to change this world and improve living conditions (Lipson 2004:205). Identity is not given, but, based on the thought and self-understanding that accompany human existence, embedded in the narrative as a cognitive and time structure, the basic function of which is to give a holistic sense and coherence to a series of events, intentions, actions, and unforeseen circumstances (Strauss 1959).

Any visible bodily defects, deformations, or features that deviate from the standard, such as a disability, provide the identity of an individual with different content. This happens because identity is very clearly and visibly related to a person's physical appearance and biological characteristics. It does not alter the cultural orientation or worldview fundamentally, but it often situates group members who are believed to be different because of their appearance or mental qualities on the margin of group life. Through stigmatization, it condemns them to life on the margins or with special status (Shakespeare 1996:96). As a consequence, such people define themselves in categories of stigma, which often leads them to feel anxiety or worry, especially since they may be discriminated against and excluded due to their differences. If people expect that those with certain features that are perceived as disavowing see themselves as worse in some way, their self-esteem will be lower. Thus, a central notion of stigmatization is the self-esteem and self-evaluation of the stigmatized people (Czykwin 2008:44).

According to Erving Goffman (1963:155), the existence of stigmatized people is determined in almost all respects by a society of people who identify themselves as normal (normals), both in terms of determining a certain life sphere for themselves and subordinating themselves to social control, which may be related to creating separate enclaves of "misfits." Furthermore, Goffman (1961) highlighted the fact that significant factors that determine the manner of conduct and self-identification of an individual constitute a part of social reactions. Pub- 
lic response to a given behavior supports not only its consolidation, but it also changes the manner of defining the identity of a "stigmatized" person. According to Howard S. Becker, a negative feature ascribed to a person becomes generalized by the environment. This, in turn, means that within the course of further negative stigma an individual is inclined to identify oneself with the ascribed role. Such experiences were shared by the respondents, who saw their disability in the behavior of those around them (Niedbalski 2015b). How others approached them somehow reflected the disability of the respondents. Hence, those around them consolidated the people's with a disability belief about their "otherness" and meant that they were unable to think about themselves in categories other than being not fully capable.

In Erving Goffman's categories of analysis, stigmatized people are characterized by having a spoiled identity, because stigmatization leads to their social exclusion regarding their features, which are disqualifying in other people's eyes. The problem of stigmatized people is related to the desire to be like anyone else, meaning "normal." This leads to permanent negotiations carried out by the stigmatized individuals regarding their image in terms of societal beliefs and commonly adopted stereotypes versus owning this stigma and its consequences (Darling 2013:3). Goffman (1963) stresses that stigmas are social constructs, not qualities of social actors, because the differentiation between "normal" and "stigmatized" people is only a perspective that emerges within the course of individuals' responses to certain features of stigmatized people. According to Goffman (1963:31-34), stigmatization means that an individual's identity adversely deviates from the expected identity, that is, a certain socially desirable model of "normality." Therefore, stigmatization poses a certain type of symbolic designation, at the same time enforcing a status to which an individual is subjected to. Therefore, the readiness of people with a disability to undertake any actions decreases, not to mention they do not have effective defense mechanisms against the negative social perception of their situation (Stryker 1980:129-135). Hence, people with a disability experience deep, often irreversible socialization, which results in acquiring a lower social status, but they also produce a deviant picture of themselves (cf. Goffman 1963). As a result, this may lead to further social degradation, which takes the form of self-marginalization, meaning, the self-limitation of people with disabilities in their perception of opportunities, perspectives, as well as determining and striving for life goals (Ostrowska 1994). This, in turn, causes a gap between the socially expected identity of an individual and their real identity (Strauss 1959). ${ }^{1}$

At the same time, certain efforts are constantly being made to overcome the disadvantages of people with disabilities. Very often they take the form of activities aimed at extracting the potential of these people, by activating them in various areas of life. One such form is the sport, which not only promotes the improvement of an individual's physical condition, helps to compensate for specific dysfunctions of the body, encourages the initiation and development of one's activity, but also creates space for building interpersonal interactions. The sport will

\footnotetext{
${ }^{1}$ Goffman's (1963) concept of stigma has had enduring scholarly influence. As Sharon Barnartt (2017) states, Goffman's concept has had a major influence on sociological views of disability by casting it as a form of deviance. British sociologists of disability, such as Paul Abberley (1987) and Colin Barnes (1998), challenge Goffman's emphasis on deviance. Instead, they argue that being cast in a deviant role not only places the person with a disability in a devalued position but also the symbolic interactionist treatment of disability ignores oppression and the material structures supporting it (Charmaz 2019).
} 
also have a special role in strengthening the self-esteem of the disabled (Molik, Morgulec-Adamowicz, and Kosmol 2008:12).

\section{Data and Methods}

Taking into account the theoretical references mentioned above, I refer to the subjective perspective of the participants, using their point of view as the basis to construct theoretical generalizations. Hence, the research materials adapted in this work are composed of the personal experiences of people who lost their physical abilities due to various random events. Unstructured and narrative interviews were performed. While triangulating the data, the study also exploited records from observations made during meetings devoted to therapy and medical consultations.

The research was carried out between 2014 and 2017 in rehabilitation centers intended for/adjusted to the needs of people with a disability across Poland. ${ }^{2}$ There were, in total, 74 in-depth unstructured interviews carried out along with almost 30 observations made during rehabilitation stays, among others. The group of subjects included people with disabilities, as well as the people who took care of them, that is, rehabilitators, physiotherapists, consultants, specialist doctors, and instructors.

The selection of subsequent cases for the study was of theoretical character (theoretical sampling), based on the constant comparative method. Thanks to theoretical sampling, the researcher, while collecting, coding, and analyzing the materials, decided on an ongoing basis where and what kind of data to col-

2 The research was carried out as part of a project financed by the National Science Center (2015/17/D/HS6/00184). lect next (Glaser and Strauss 1967; Charmaz 2006). While applying the constant comparative method in my search for other data, I attempted to choose cases that are both highly various and similar to each other, to grasp a maximum number of conditions differentiating the categories and their mutual correlations (Charmaz 2006; Glaser and Strauss 1967:45-53). Doing so resulted in there being people representing different types of motor disabilities in the examined group. These included people with four- and two-limb paralysis, cerebral palsy, and lower limb(s) amputations. In the selection of subsequent cases, I also took into account such variables as the type of sport or the period of practicing it. The selection of cases lasted until the theoretical saturation of the generated analytical categories was achieved and served to differentiate the comparisons made at a given stage of the study, as well as to increase or decrease the case variation, capture the variability of conditions and replenish the database (Glaser and Strauss 1967).

The premises that support the selection of the above-mentioned techniques arise, firstly, from the accepted ontological (human experiences, interpretations, knowledge, evaluations, interactions perceived as significant interdependencies of the social reality) and epistemological assumptions (the legal manner of data generation based on those ontological assumptions comprised of interactions, conversations with people, listening to stories, and obtaining access to the knowledge, evaluations, and impressions of individuals). Secondly, the obtained data are complete and in-depth, which complies with the ideas put forward by Rubin and Rubin (2005), according to whom qualitative research should be applied in the case of notions that require deeper comprehension, and this is served best by detailed examples and expanded narrations. 
The analysis of the research material was performed according to grounded theory methodology (Glaser and Strauss 1967; Strauss and Corbin 1990; Konecki 2000). The motive for selecting this method was the need to identify the "factual" ways of life, the actions of the individuals, the processes of creating meaning, and therefore-the desire to bring science closer to "life" and recognize social reality from the perspective of the subject that creates it (Wyka 1993:34). Furthermore, the biographies and their construction in time must consider the individual's life perspective. At the same time, all biographical materials are a potential source of data on the identity of a person talking about his or her life, as he or she interacts with the listener/reader as a social actor endowed with a specific set of self-definitions (cf. Prus 1999).

Selecting subsequent cases was theoretical, based on the method of constant comparison, which means that subsequent cases were chosen based on current analytical determinations, not according to assumptions decided on beforehand (Glaser and Strauss 1967:45). The selection of cases lasted until theoretical saturation of the generated analytical categories was achieved.

\section{Findings}

The people with disabilities who participated in the study experienced clear physical and psycho-social discomfort related to the dysfunction of their bodies. The problems with their body hindered their lives, and in some cases even rendered it impossible to function independently and "normally" (Niedbalski 2015a:226). What is more, because of its limitations, a dysfunctional body was perceived by the researched group as a source of suffering. According to the individuals, it was their bodies that controlled their lives, not them, and forms of this power were determined by resistance, experienced in various activities of everyday life.

I was unable to do a lot of things. Actually, I was able to do nothing on my own. Someone needed to help me clean myself, get up, get dressed...I was even unable to get to the toilet on my own. It was torture; I thought I wouldn't be of any use anymore. [i.5.16 $]^{3}$

As Katarzyna Kowal writes (2012:170), “a person suffering because of bodily dysfunctions is, first of all, their own body. They perceive and define themselves in bodily terms over everything else." This is how bodily limitations reduce the respondents to their bodies, thus embodying their "self." It is related to losing the "sense of normality," but also having some socially acquired patterns of this "normality," and being aware that they are not fulfilled (Niedbalski 2015a:226). The researched individuals shared a common ground in that they felt depreciated in the eyes of other people, being seen as "odd" and "other," because of their disabilities. All of this meant that they were unable to escape from feelings of shame and humiliation which they felt concerning others, especially able-bodied individuals. They saw the source of their limited self-confidence in their body dysfunction. They believed that they would not be accepted and that they would not find any understanding among able-bodied individuals (cf. Charmaz 1991). Hence, they could not reveal their disabilities to those people (in fact, they made every attempt to hide it); at the same time, they were afraid of being exposed (Fitzgerald and Paterson

\footnotetext{
${ }^{3}$ I use indications of the quoted fragments of my respondents' statements throughout the article, where the letter " $\mathrm{i}$ " means an interview, the first figure indicates the number of the interview, and the last figure is the year when the interview was carried out. For example, the indication i.5.16 means that it was the $5^{\text {th }}$ interview carried out in 2016.
} 
1995:15). If it could not be hidden, then the people avoided contact with others, especially strangers, and tried not to show themselves in public space. As a result, they were pushed to self-exclusion, which related to almost every aspect of their lives:

It was simply humiliating for me; I was afraid that someone would see me. I used to be a big man, I had strength, others respected me, and after the accident, I was unable to wipe my bottom. This is what was most disturbing for me. Not even the fact that I would need to deal with it for the rest of my life, but that the others, who remembered me as a real man, would now see a cripple who could do nothing. [i.12.15]

Although a stigma ascribed by society is often a very strong determinant in shaping their lives, stigmatized individuals may still try to engage in actions which might enable them to fight the sense of inferiority, thereby limiting or minimizing the negative influence and pressure exerted by the environment (Coleman-Fountain and McLaughlin 2013). If emotions connected with such a set of self-definitions provide a source of strong discomfort or suffering for an individual, they may start searching for new ways to characterize themselves (Brune and Wilson 2013). Hence, a social actor whose attitude is active when compared to the stereotype may transform this negative image of themselves and reject any harmful stigmatizations, thus obtaining a definition of a person who is an exception to a rule. This can redefine the concept of self and any negative attributes related to the stigma, so they become a source of positive self-evaluation (Goffman 1963:42-43). ${ }^{4}$

${ }^{4}$ Erving Goffman quotes statements made by people with disabilities that are related to their special sensitivity in perceiving themselves and the world as a result of their physical disorders (Goffman 1961).
Based on my research, it was found that "freeing" oneself from the feeling of stigmatization and the biographic "breakup," moving towards a new plan of action and redefining the self, and one's role takes place within a three-dimensional process. Firstly, there is focusing on oneself, which means introspection of " $I$ " and concentrating on interactions with one's body. Secondly, there is changing of the object of comparison, for instance, seeking a new reference group and significant others. Thirdly, there is a revision of the social identity, meaning, the development of a strategy of coping with a public proclamation of disability and presenting oneself. These are not separate phases, as they overlap one another to various degrees and in different scopes. It means that, for particular people, their biographies will have overlapping phases, mentioned above, meaning that the course is not stadial but synchronous.

\section{The Bodily Transformations and the Process of Reconstructing the Self by a Person with a Disability Who Practices Sport}

A body marked by a disability remained a stigma for the participants, especially in social relationships, where it became a reason for discrimination. The respondents stated that they did not like their bodies and that they were ashamed because they differed from generally accepted norms. The same relates to a dysfunctional body, which meant that these people tried to hide their handicaps and mask their deficits (Vickers 2014; Oldfield et al. 2018). Not until they undertook a given type of physical activity (e.g., professional work, sports practicing, etc.) with its accompanying experiences did a gradual and positive transformation in the perception of their disabilities begin. As emphasized by the individuals, it was connected with becoming familiar with their bodies and their possibilities "again." 
These individuals very often realized that something they had once found hard or even impossible could be achieved thanks to practicing sport. Hence, the boundaries of not only their bodies but also their belief in their strengths changed. The vision of the individual changes; he/she goes from being a feckless and dependent person to an individual who is capable of acting in a manner and scope that they were unfamiliar with.

You know, a man doesn't know himself until he faces a particular situation until he tries to do something, especially if it seems impossible. And that was the case with me. I also didn't believe that I could do something with myself, that I could be so capable at all...This is what sport gave me. [i.5.17]

For the participants, activity became a route that could be followed to support the process of accepting themselves and their disability more effectively. The people with a disability gradually began to perceive their disabilities differently. In the beginning, the changes took place slowly, and they got bigger and clearer with time. It was accompanied by intensive work on their bodies, which they had to do (Niedbalski 2015a:332). It usually involved complying with particular regimes related to, among others, intensifying certain actions and gaining a higher level of self-control. It is worth mentioning here that the individuals usually realized that by neglecting their physical activity they would cause not only the functional regression of their bodies but also some damage to their "external image" (Kowal 2012:190).

I got involved because I can see the effects, because it's important to me, and I can't imagine that it could be different, like it was some time ago. It costs a lot of energy and time, but it's my life now, and I need to subordinate myself to it if I want to get something out of it. [i.12.15]

In their lives, the activity they chose to get involved in became the factor responsible for the process of regaining faith in themselves and their possibilities. It also provided a source of belief in their value and in the fact that despite having a physical dysfunction, they remain fully-valuable and entitled members of society. In this way, the people with disabilities carried out an internal dialog regarding, on the one hand, the way they see themselves, and, on the other hand, the way others see them (cf. Cooley 1922:184). Such a dialog, in both cases, was determined by certain stimuli from the environment. The more positive the stimuli, the higher the degree to which the person with a disability was able to develop a more beneficial image of themselves, and the quicker they were able to "get over" the traumatic experiences connected with the situation that led to their disabilities.

A person with a disability who took up an activity began to perceive their disability differently. There were slow changes at the beginning, but over time they got bigger and clearer, which was related to "training" the body's capacity. Transformations in the life of an individual pursuing a given form of activity meant that they gained more capacity and thus control over their bodies, which is well-illustrated by the fragment below of one of my interviewees.

There is an improvement, a significant improvement in shape, health, and mood. My regular exercising has definitely had an impact on my agility. I remember that my friend, who hadn't seen me for a couple of years, was really surprised that I had changed so much [laughing]. And I think this is the best evidence of how my activity affects me. [i.20.17] 
A handicapped body with dysfunctions was not perceived by the disabled as something to be ashamed of or to be hidden. While observing the changes in their bodies, they became satisfied and self-fulfilled. Therefore, a disabled body, which quite often had been a reason for stigma, negative emotions, or even humiliation, was no longer associated with such experiences (Niedbalski 2015a:334). This is how the body, as an outline of the actions and practices of an individual, became a significant element of constructing the feeling of identity, through engaging in a given type of activity, and the control that had provided a basic resource to maintain this biographical continuity (Goodley 2011).

\section{The Role of Significant Others in the Process of Reconstructing the Identity of People with Disabilities Who Practice Sport}

In the process of reconstructing an identity special significance is given to contacts, interactions, and bonds with others whom the people with disabilities encounter at various levels of social life. A central place in confirming (and shaping) the identity is occupied by significant others, that is, people who the individual is related to through intensive and emotional relationships (Berger and Luckmann 1979:170-171). Anselm Strauss (1959:132) devoted considerable attention to the relationship between the self and significant others. He claimed that maintaining a coherent definition of self by an individual depends on the positive validation of each new element of their identity. Rejecting such a validation means reinterpreting the individual's actions, which means reinterpreting the concept of oneself. Strauss noticed that the feeling of being an integral part of the group they belong to plays a significant role in an individual's perception of self. As he wrote, "a path of the group becomes the path of the individual, and mistakes of the group become its mistakes" (Strauss 1959:41).

While choosing a given type of life activity (e.g., professional work), the interviewees gained the possibility to become members of groups that other people with disabilities often belonged to. In such a situation these people perceived themselves as an integral part of that group and identified with its goals. Participation in such a community was connected with socialization processes that involve not only shaping collective identity, but also the potential (re)construction of the whole self-definition of the social actor. Through observing and identifying with others a person with a disability internalized new roles, accompanying identities, motivational and interpretation schemes, as well as various entitlements, regarding their social value (cf. Berger and Luckmann 1979:151-155).

In this context, the notion of a reference group may also be applied as a comparative scheme concerning which people form basic judgments and evaluations regarding their social position. It also provides measures and criteria that allow them to determine their social position, which constitutes a basis for the individual developing one's self-esteem (Kuhn 1972:175). A person with a disability compares their social position with that of others, which results in identifying with groups of a similar level of relative privileges or disabilities and adapting their attitudes and patterns of behavior (Merton 1949). Within such groups the individual agrees on plans of actions and permanently reinterprets the reality while interacting with its members, leading to a discussion with oneself. Thanks to those interactions and particular auto-narrations the individual obtains a key to interpreting one's place in the world and the things that should be done in a given situation (Mead 1934). 
After the accident, I was down in the dumps. My world actually collapsed. I thought it would be better if I had died and not become disabled. It was a hard time, so when Maria [name changed-JN] came and said that I could do this or that and that people such as myself can even play, I thought she was nuts. Despite all of this I wanted to get out, as I could not sit in that cage anymore. I listened to reason... Now I know that it was the best thing I could have done in that situation. It let me take a different look at my life, set free from dark thoughts, and I think that I can still live, work, and function among other people relatively normally. [i.14.17]

Such positive empowerment, which is created thanks to building group bonds, as well as the possibility of showing a person with a disability that he/she can still function in society, is, on the one hand, an important resource to realize one's life plans. On the other hand, it supports self-acceptance. From this perspective, individuals become subjects of consideration for themselves. This process is additionally enhanced by people in the group who became especially important for the individual (they obtain the status of significant others) as they play the role of guides, teachers, and mentors. Such people may also become guardians of the individual's biography, exerting a strong influence on their identity and faith. The notion of coaching, introduced by Anselm Strauss (1959:111), might describe the relationships between a person with a disability practicing sport and someone who becomes a "signpost," pointing to the desired action. Such a relationship is most often established between people who are characterized by certain features that are significant in a given situation. The main qualities of the coaching relationship are rooted in the fact that a pupil needs a guide while going through subsequent stages (Niedbalski 2015b:39). It applies not only to the conventional sense of teaching skills, but also the fact that while the "coached" person is moving within the social space, there are highly important processes taking place which require an explanation, and this is where the "coach" plays a crucial role. These notions are also raised by Bourdieu and Wacquant (2001:220), who emphasize that "teaching the professions, craft, vocation...requires a pedagogy that is slightly different from the one applied in knowledge acquisition... There are numerous ways of thinking and acting, often livelier ones, transferred in a practical form, in a whole communication, and thanks to practices based on direct contact between the one teaching and the one being taught." While these authors highlight characteristics of the "teaching" process, Strauss refers in this context to identity transformations, which become a part of the "student" themselves.

\begin{abstract}
Alex was a coach of ours here, as far as I remember. I think it has always been like this; that's what I heard. And when I came here, he took care of me, showed me around, explained the principles and everything, he simply took care of me. I felt more confident when he was here, telling me what to do. Others also listened to him because he knows a lot, and he played professionally in the past. [i.10.16]
\end{abstract}

A highly significant element of the coaching is the schedule. A coach-guide needs to take care of the balance while going through subsequent stadiumsthey cannot allow themselves or their wards to be impatient, nor permit any sluggishness. Various tactics may be applied while trying to maintain this balance. One of them is prescribing how to acthow to find fulfillment and succeed in a given type of physical activity. Therefore, the coach's role is to point out what needs to be done, what you need to 
distinguish yourself, which qualities need to be developed, and which need to be gotten rid of. In one word, it is a formula that may not guarantee success on its own, but the application of which may bring someone closer to their goal.

Coaches also apply "tactics," namely, a schedule that determines the subsequent steps people with disabilities need to follow to progress gradually. A coach introduces different people at different stages of their development, not only shaping their career but also exerting an influence on their biography (Niedbalski 2015b:39). Therefore, they perform continuous work on the individual's biography and identity. For a person with a disability, completing each stage means they have not only achieved subsequent levels but that they are pushing their own, often symbolic, boundaries. Therefore, a coach might not only motivate a person with a disability, but they may also trigger positive emotions related to the successes which pertain to completing subsequent challenges.

The people with disabilities who practice sports often mentioned the exploration of the "unknown possibilities" and "unidentified potential of their bodies." In other words, this was the process of learning about the possibilities of their bodies, which were related mostly to their physical capacity (Jakubowska 2009:95). While analyzing the interviews with people with disabilities, we can distinguish situations where the individuals discovered that something that had seemed difficult or even impossible to do (for example, a given action) became achievable thanks to this activity and that the individuals not only pushed the limits of their bodies but also the boundaries of their faith in their strength. That meant that the vision of themselves changed from being a person who was often dependent on others to someone capable of acting in a manner and scope that they had been unfamiliar with.

When Mark came to me for the first time when I was still at the hospital and he told me that I would be doing the long jump, I looked at him like he was nuts, because how was I supposed to do that with one leg... You know, a guy comes to you and says that you can do this or that, and you are lying in bed, and you can't even move very much. [i.4.16]

The activity of people with disabilities supports positive thinking about themselves and their possibilities, which leads to the fact that the disabled ascribe a higher value to their "life vitality" than to the other life spheres. It may symbolize a bridge between different types of actions undertaken by a person with disabilities, and it means that the activity may be a source of inspiration, but also the creation of internal power. From this perspective, an especially significant aspect-as suggested by the people with disabilities -is that they regain the belief in their possibilities, leading to the reconstruction of life goals and priorities. It very often means they are more open, which in turn supports their progress in life, both in the private and public spheres. Within the first sphere, it concerns courage in establishing friendships and potentially establishing romantic relationships. On the other hand, the courage and self-esteem derived from an activity such as practicing sport mean that an individual starts to present a more definite and assertive attitude in regular, everyday relationships.

\section{Public Presentations as a Proclamation of One's Identity}

Anselm Strauss (1959:9) believed that each of us presents ourselves to others (and ourselves) by 
looking in the mirror of their judgments. In such a context, some of the disabled believed that they would not be accepted or understood by the able-bodied. This meant that they were unable to reveal their disabilities in front of others, and were afraid of being exposed. Here it is worth recalling the words of Erving Goffman (1963) who believed that people with a stigmatizing feature are afraid of a lack of acceptance from their environment. This, in turn, pushes them to self-exclusion and social isolation.

On the other hand, as suggested by Strauss (1959), an individual may reject imposed definitions, adapting a clear identity project. Therefore, the moment of public performance is of great importance to a person with a disability. This is when a person may reveal him/herself in an open (public) space, for example, by taking part in get-togethers. Such a situation includes some elements of Strauss's meeting a challenge, but it is also related to the public proclamation. According to Strauss (1959), it is an individual's statement about their views or attributes. It is a passage in the process of exposing a person with a disability to a larger group of-importantly-able-bodied people. What is more, it suggests that a person with a disability encounters another turning point in their biography when they decide to expose their dysfunction in a wider social framework (Niedbalski 2015a:331).

For me, the first performance in front of an audience was unique. When you see all those people who are observing you, looking at you, and you don't know what they're thinking, it's really paralyzing. You have thought then-wouldn't it be better to run away, to pull the plug on it? But, it would mean that you gave up halfway, you'll be defeated by your own fears. [i.17.16]
In such conditions, a person with a disability needs to make a qualitative jump in their biography, which involves revealing to the public the hidden qualities of their bodies. Such situations may be compared with the open context of awareness described by Barney Glaser and Anselm Strauss (1965), where the parties of the interaction do not hide the existence of a certain situation-in this case, disability. The audience knows whom they are dealing with, and they make no comment and do not belittle them. Meanwhile, the social actor does not try to hide the attributes which are an indispensable part of them (and which, according to them, are belittling), and this is reflected in how they perceive themselves (Niedbalski 2015a:332):

For me, it was almost like, I don't know how to put it, simply like something unreal...that I took the plunge and took off the prosthesis with everyone around, simple as that. But, it was easier than I'd thought because I wasn't thinking that I was removing the prosthesis; in my mind, I was in a different place. I thought more about the competition, about the game, the result, that I'd need to sweat, to do my best. And this was what counted, nothing else. And when I understood that it can be done, that this is what it is, I stopped being afraid of showing myself without the prosthesis, that others could see me what I really am like. And I told myself that when you don't think about it so much, you can do a lot more when you aren't afraid and blocked anymore. [i.19.16]

The activities pursued by the participants became a path they could follow to support the process of accepting themselves and their disability more effectively. The moment they took up the activity was often a breakthrough in the individual's biography and the beginning of transformations in the dimensions of their self-definition. 


\section{Conclusions}

The people with a disability who participated in the study experienced clear physical and psycho-social discomfort related to the dysfunction of their bodies. According to their statements, a body with dysfunctions hindered their functioning. What is more, they perceived a dysfunctional body as a source of suffering, caused by its limitations. According to the respondents, their bodies took control, and forms of this power were determined by resistance, which was observable in various activities of everyday life. For example, this resistance might be manifested in their inability to perform even the simplest activities, such as tying laces if the person did not have a working hand, or moving around freely if the dysfunction of the body consisted of limited use of the legs. This is how bodily limitations reduce the respondents to their bodies, thus embodying their "self." It may be related to losing the "sense of normality" and being aware that they are deviating from socially acquired patterns of it in one way or another. A disabled body becomes an observable one, having lost many of its original embodied schemes (Olney and Brockelman 1991:86). Therefore, it is permanently present in an individual's life, showing itself not in a strictly physical sense, when they are unable to do some things, but it also exists in a psychophysical dimension, as the awareness of "otherness" (Niedbalski 2015a:227). An incomplete, faulty, or deformed body violates the applicable socio-cultural standards on corporeality because of its dysfunctional nature and "ugly" appearance. It is also worth recalling what Thomas Osborne said in this context. He stated that stigma is an element that does not allow us to forget about the body, the stigma being the bodily memento which hinders liberation from the body-and this becomes the main problem for people with disabilities (Osborne 1997). A disabled body, although stigmatized by the disability, is not a stigma in itself. However, in social relations, anything that bears the imprint of disability or dysfunction can still be a source of discrimination.

This research demonstrates that people with disabilities who are active in various spheres of their lives can overcome negative experiences. Being active allows people with various dysfunctions not only to change how they perceive themselves but also to influence the way they are perceived by those around them. Through their actions, including successive, repeatable, and planned physical activities, people with disabilities may improve their psycho-physical condition, gain additional practical skills, and significantly enhance their functional fitness (Niedbalski 2017:227). Furthermore, an active person (e.g., one who practices sports) starts to perceive their body in categories other than those arising from their disability and body dysfunctionality.

Although sports activity does not eliminate the damage to health itself, it does make it possible to strengthen those areas of the body that can, to some extent, take on the role of dysfunctional spheres. In this way, the general condition of the whole body improves, and thanks to regular exercises the person with a disability has greater motor coordination and better control of their bodies. In many cases, an individual can achieve a level of efficiency that gives them a high degree of autonomy and freedom, and consequently significantly reduces their dependence on other people. In this way, the person with a disability gains a sense of greater control over their own life, which is reflected in a sense of the quality of life.

Crossing subsequent mental and physical barriers moves the people with disabilities away from the 
feeling of the attached stigma and allows them to define themselves in new and "normalized" categories. The body is no longer an impassable barrier, and it acquires a new, unknown face that emphasizes the underlying potential and unexplored possibilities. The awareness of their bodies, improved through the activity, allows a person with a disability to experience stimuli in a controlled manner, flowing from the outside; on the other hand, it makes it possible to control the body itself, its functioning, its condition, and its reactions (Snyder and Mitchell 2001:373). A body, as a system of actions and the source of practices, becomes a significant element when developing the feeling of self-identity through participation or involvement in physical activity, and the regulated control over their bodies becomes a basic resource for maintaining biographic continuity and identity. This takes place through the work on the body and the identity carried out in two dimensions-through rejecting the stigmatized identity and through reconstructing and maintain-

\section{References}

Abberley, Paul. 1987. "The Concept of Oppression and the Development of the Social Theory of Disability." Disability, Handicap E Society 2(1):5-19.

Barnartt, Sharon N. 2017. "How Erving Goffman Affected Perceptions of Disability in Sociology." Pp. 29-37 in Sociology Looking at Disability: What Did We Know and When Did We Know It? Research in Social Science and Disability, edited by S. N. Barnartt and S. B. Green. Bingley: Emerald Group.

Barnes, Colin. 1998. "The Social Model of Disability: A Sociological Phenomenon Ignored by Sociologists?" Pp. 65-78 in The Disability Reader: Social Science Perspectives, edited by T. Shakespeare. London: Cassell. ing the belief in their "social normality." Both processes merge, becoming complementary elements of one whole, namely, the identity transformations of an individual. At the same time, both courses of action are never fully completed, and they must be seen as an ongoing process.

In this context, a dysfunctional body-as given by nature or resulting from life incidents and circumstances-is a starting point, the beginning of a project created by an individual (Kuppers 2004:45). The activity shown here, which influences the corporeality, boosts the confidence of the person with a disability. Instead of feeling imprisoned in their bodies, they get a sense of control over their bodies and, as a consequence, over their lives. This is how a body, even a disabled and dysfunctional one, may become a form of capital, provided that the individual goes beyond one's biological perceptions alone, and thinks of the body as a "material" which can be transformed, modernized, and improved (cf. Leder 1990).

Berger, Peter and Thomas Luckmann. 1979. The Social Construction of Reality. A Treatise in the Sociology of Knowledge. London: Penguin Books.

Blumer, Herbert. 1969. Symbolic Interactionism: Perspective and Method. Berkeley, CA: University of California Press.

Bourdieu, Pierre and Loïc J. Wacquant. 2001. Zaproszenie do socjologii refleksyjnej [An Invitation to Reflexive Sociology]. Warsaw: Oficyna Naukowa.

Brune, Jeffrey A. and Daniel J. Wilson. 2013. Disability and Passing: Blurring the Lines of Identity. Philadelphia, PA: Temple University Press. 
Carey, Allison C. 2013. "The Sociopolitical Contexts of Passing and Intellectual Disability." Pp. 142-166 in Disability and Passing: Blurring the Lines of Identity, edited by J. A. Brune and D. J. Wilson. Philadelphia, PA: Temple University Press.

Charmaz, Kathy. 1991. Good Days, Bad Days: The Self in Chronic Illness and Time. New Brunswick, NJ: Rutgers University Press.

Charmaz, Kathy. 1994. “'Discoveries' of Self in Illness.” Pp. 226242 in Everyday Life: Ethnography as Lived Experiences, edited by M. L. Dietz, R. Prus, and W. Shaffir. Mississauga: Copp Clark Longman.

Charmaz, Kathy. 1995. “The Body, Identity, and Self: Adapting to Impairment." The Sociological Quarterly (36)4:657-680.

Charmaz, Kathy. 2006. Constructing Grounded Theory. A Practical Guide through Qualitative Analysis. Thousand Oaks, CA: Sage.

Charmaz, Kathy. 2019. “Experiencing Stigma and Exclusion: The Influence of Neoliberal Perspectives, Practices, and Policies on Living with Chronic Illness and Disability." Symbolic Interaction 43(1):21-45.

Charmaz, Kathy and Dana Rosenfeld. 2006. "Reflections of the Body, Images of Self: Visibility and Invisibility in Chronic Illness and Disability." Pp. 35-50 in Body/Embodiment: Symbolic Interaction and the Sociology of the Body, edited by D. D. Waskul and P. Vannini. London: Ashgate.

Coleman-Fountain, Edmund and Janice McLaughlin. 2013. “The Interactions of Disability and Impairment." Social Theory and Health 11(2):133-150.

Cooley, Charles H. 1922. Human Nature and the Social Order. New York: Charles Scribner's Sons.

Crocker, Jennifer and Brenda Major. 1989. "Social Stigma and Self-Esteem: The Self-Protective Properties of Stigma." Psychological Review 96(4):608-630.

Czykwin, Elżbieta. 2008. Stygmat społeczny [Social Stigma]. Warsaw: Wydawnictwo Naukowe PWN.

Darling, Rosalyn B. 2013. Disability and Identity: Negotiating Self in a Changing Society. Boulder, CO: Lynne Rienner Publishers.

Fitzgerald, Maureen H. and Kathryn A. Paterson. 1995. "The Hidden Disability Dilemma for the Preservation of Self." Journal of Occupational Science 2(1):13-21.
Glaser, Barney and Anselm L. Strauss. 1965. Awareness of Dying. Chicago: Aldine.

Glaser, Barney and Anselm L. Strauss. 1967. The Discovery of Grounded Theory. Strategies for Qualitative Research. Chicago: Aldine.

Goffman, Erving. 1961. Asylums: Essays on Social Situation of Mental Patients and Other Inmates. Garden City, NY: Doubleday Anchor Book.

Goffman, Erving. 1963. Stigma. Notes on the Management of Spoiled Identity. Englewood Cliffs, NJ: Prentice-Hall.

Goodley, Dan. 2011. Disability Studies. An Interdisciplinary Introduction. London: Sage.

Heatherton, Todd F. et al. 2007. Społeczna psychologia piętna [The Social Psychology of Stigma]. Warsaw: Wydawnictwo Naukowe PWN.

Jakubowska, Honorata. 2009. Socjologia ciata [The Sociology of the Body]. Poznan: Wydawnictwo Naukowe UAM.

Kirenko, Janusz. 2006. Oblicza niepetnosprawności [The Faces of Disability]. Lublin: Wyższa Szkoła Społeczno-Przyrodnicza im. Wincentego Pola w Lublinie.

Konecki, Krzysztof. 2000. Studia z metodologii badań jakościowych. Teoria ugruntowana [Studies in Methodology of Qualitative Research. Grounded Theory]. Warsaw: Wydawnictwo Naukowe PWN.

Konecki, Krzysztof. 2015. “Anselm L. Strauss - pragmatyczne korzenie, pragmatyczne konsekwencje [Anselm L. StraussPragmatic Roots, Pragmatic Implications]." Przeglad Socjologii Jakościowej 11(1):12-39.

Kowal, Katarzyna. 2012. “Doświadczanie własnej cielesności przez biorców kończyny - socjologiczne studium zrekonstruowanego ciała [Limb Recipients' Experience of Their Own Corporeality-Sociological Study of Reconstructed Body]." Przeglad Socjologii Jakościowej 8(2):152-199.

Kuhn, Manfred. 1972. "The Reference Group Reconsidered." Pp. 171-184 in Symbolic Interactionism: A Reader In Social Psychology, edited by J. G. Manis and B. N. Meltzer. Boston: Allyn and Bacon.

Kuppers, Petra. 2004. Disability and Contemporary Performance: Bodies on Edge. New York: Routledge. 
Leder, Drew. 1990. The Absent Body. Chicago: University of Chicago Press.

Lipson, Juliene G. 2004. "Multiple Chemical Sensitivities: Stigma and Social Experiences." Medical Anthropology Quarterly 18(2):200-213.

Major, Brenda and Laurie T. O’Brien. 2005. “The Social Psychology of Stigma." Annual Review of Psychology 56:393-421.

Marciniak, Łukasz. 2015. “Teorie pracujące. Pragmatyzm w ujęciu badaczy z grupy Chicago School Irregulars [Working Theories. Pragmatism as Defined by the Researchers From Chicago School Irregulars Group]." Przeglad Socjologii Jakościowej 11(1):40-53.

Mason, Michelin. 1990. “Internalized Oppression.” Pp. 10-26 in Disability Quality in the Classroom, edited by M. Maynard and J. Purvis. London: Taylor and Francis.

Mead, George H. 1934. Mind, Self and Society. Chicago: University of Chicago Press.

Merton, Robert K. 1949. Social Theory and Social Structure. New York: Free Press.

Molik, Bartosz, Natalia Morgulec-Adamowicz, and Andrzej Kosmol. 2008. Zespołowe gry sportowe osób niepetnosprawnych. Koszykówka na wózkach i rugby na wózkach [Team Sports Games for People with Disabilities. Wheelchair Basketball and Wheelchair Rugby]. Warsaw: AWF im. J. Piłsudskiego w Warszawie.

Niedbalski, Jakub. 2013. Żyć i pracować w domu pomocy społecznej. Socjologiczne stadium interakcji personelu z upośledzonymi umystowo podopiecznymi [Living and Working in a Social Welfare Home in Poland. A Sociological Study on the Interaction of Personnel with Mentally Handicapped Charges]. Lodz: Wydawnictwo UŁ.

Niedbalski, Jakub. 2015a. "Przemiany percepcji własnego ciała przez osoby z niepełnosprawnością fizyczną uprawiające sport [Changes in the Perception of One's Body by People with Physical Disabilities Practicing Sport]." Studia Socjologiczne 3(218):221-240.

Niedbalski, Jakub. 2015b. "The Role of Sport in the Reconstruction Process of the Identity of a Person with an Acquired Body Dysfunction." Przegląd Socjologii Jakościowej 9(3):26-45.

Niedbalski, Jakub. 2017. Wymiary, konteksty i wzory karier. Proces stawania się sportowcem przez osobę z niepetnosprawnościa fizyczna - analiza społecznych mechanizmów (re)konstruowania tożsamości [Dimensions, Contexts, and Career Patterns. The Process of Becoming an Athlete by a Person with Physical DisabilityThe Analysis of Social Mechanisms of (Re)Constructing Identity]. Lodz: Wydawnictwo UŁ.

Oldfield, Margaret et al. 2018. "'You Want to Show You're a Valuable Employee': A Critical Discourse Analysis of Multi-Perspective Portrayals of Employed Women with Fibromyalgia." Chronic Illness 14(2):135-153.

Olney, Marjorie F. and Karin F. Brockelman. 1991. “The Impact of Visibility of Disability and Gender on the Self-Concept of University Students with Disabilities." Journal of Postsecondary Education and Disability 18(1):80-91.

Osborne, Thomas. 1997. "Body Amnesia-Comments on Corporeality." Pp. 188-204 in Sociology after Postmodernism, edited by D. Owen. London, Thousand Oaks, New Delhi: Sage Publications.

Ostrowska, Antonina. 1994. Badania nad niepełnosprawnościa [Research on Disability]. Warsaw: IFiS PAN.

Prus, Robert. 1999. Symbolic Interaction and Ethnographic Research. Albany, NY: State University of New York Press.

Prus, Robert and Scott Grills. 2003. The Deviant Mystique: Involvements, Realities and Regulation. Westport: Praeger.

Rubin, Herbert J. and Irene S. Rubin. 2005. Qualitative Interviewing: The Art of Hearing Data. Thousand Oaks, CA: Sage.

Scheff, Thomas. 1990. Microsociology. Discourse, Emotions, and Social Structure. Chicago, London: Chicago University Press.

Shakespeare, Tom. 1996. "Disability, Identity, and Difference." Pp. 94-113 in Exploring the Divide, edited by C. Barnes and G. Mercer. Leeds: The Disability Press.

Snyder, Sharon L. and David T. Mitchell. 2001. “Re-Engaging the Body: Disability Studies and the Resistance to Embodiment." Public Culture 13(3):367-389.

Strauss, Anselm L. 1959. Mirrors and Masks. The Search of Identity. Glencoe, IL: The Free Press.

Strauss, Anselm L. and Juliet Corbin. 1990. Basics of Qualitative Research. London: Sage. 
The Role of Sport in the Process of Negotiating Identity: Dealing with the Stigma of Disability by People with Acquired Bodily Dysfunctions

Stryker, Sheldon. 1980. Symbolic Interactionism: A Social Structural Version. Menlo Park, CA: Benjamin Cummings.

Vickers, Margaret H. 2014. "Disability and Dirty Workers: Stories of Physical, Social and Moral Taint." Disability \& Society 29(9):1356-1368.
Wyka, Anna. 1993. Badacz społeczny wobec doświadczenia [Social Researcher in the Face of Experience].Warsaw: PWN.

Zakrzewska-Manterys, Elżbieta. 2010. Upośledzeni umystowo. Poza granicami człowieczeństwa [The Mentally Handicapped. Outside the Boundaries of Humanity]. Warsaw: Wydawnictwo UW.

\section{Citation}

Niedbalski, Jakub. 2020. "The Role of Sport in the Process of Negotiating Identity: Dealing with the Stigma of Disability by People with Acquired Bodily Dysfunctions." Qualitative Sociology Review 16(4):180-197. Retrieved Month, Year (http://www.qualitativesociologyreview.org/ENG/archive_eng.php). DOI: http://dx.doi.org/10.18778/1733-8077.16.4.11 